\title{
The Dispute over the Date of the Last Supper. Its Chronology Revisited
}

\author{
MARIUSZ ROSIK \\ Pontifical Faculty of Theology in Wrocław, Poland \\ mrosik@pnet.pl, ORCID: 0000-0002-1943-8649
}

\begin{abstract}
The article discusses the issue of alleged or real disagreements between John and the Synoptics regarding the dating of the Last Supper. After showing the elements of the Gospel narratives that portray the Last Supper as a paschal supper, the author outlines eight hypotheses regarding the dating of the Last Supper. Two of them seem to be the most convincing within the current state of research: the Jesus Passover hypothesis (a final Passover unique to Jesus and his followers) and the philological hypothesis.
\end{abstract}

Keywords: the Last Supper, chronology of the last days of Jesus, Passover supper, Jewish calendar

The question of dating the Last Supper revives the minds of biblical scholars from time to time and has also appeared in theological debates. It should be remembered that between John the Evangelist and the Synoptics (Mark, Matthew and Luke) there is a (real or only apparent) contradiction on the date of the Last Supper that Jesus ate with his disciples. According to Mark (and consistently, to Matthew and Luke) Jesus' supper took place on the day when the paschal lambs were slaughtered: "On the first day of Unleavened Bread, when the Passover lamb is sacrificed, his disciples said to him, 'Where do you want us to go and make the preparations for you to eat the Passover?' [...] When it was evening, he came with the twelve" (Mark 14:12.17 and parallel passages). So here we are dealing with the eve of Passover, which in the light of the chronology of the synoptic Evangelists fell on a Thursday. Things are slightly different in the narration of John the Evangelist. Following the account of the youngest apostle, the Jewish authorities leading Jesus to Pilate did not enter the praetorium "so as to avoid ritual defilement and to be able to eat the Passover" (John 18:28). Assuming the traditional interpretation of John's version, the trial of Jesus took place before the Passover supper celebrated by all Jews, and the crucifixion took place when the followers of Judaism were slaughtering the lambs for the evening ritual meal, i.e. on Friday.

Let us now reconsider the solutions to this discrepancy. Is it possible to agree John's account with the Synoptics' narration? What are the traditional (that now can be called "classic") attempts to resolve this question? What are the latest proposals? 
Or perhaps the contradiction between the Synoptic Gospels, on the one hand, and John's Gospel, on the other, is barely apparent. And finally, when did the Last Supper actually take place?

These questions will be explored in several stages. Initially, we will point out that the message given by all of the four Gospels regarding the Last Supper includes plain references to the Passover feast although not all exegetes agree that it was indeed a paschal supper (1). This stage seems necessary for a subsequent presentation of hypotheses according to which Jesus institutes his own Passover supper, slightly different from the typical Jewish Passover meal. Secondly, we will refer to the traditional solutions to the problem of the chronology of the Last Supper without a further discussion as they are commonly known to theologians (2). Next, we will introduce recent hypotheses as regards the issue of our interest (3), and finally, their assessment will be given (4).

\section{A Paschal Supper or Only Some of Its Elements?}

Before presenting solutions proposed by contemporary biblical scholars to the dilemma concerning the date of the Last Supper, we should make a general observation that may significantly influence our acceptance or rejection of any of these solutions. Obviously, it is utterly necessary for us to realise that the Last Supper, as described by the Synoptics, most probably had the character of a Passover meal. ${ }^{1}$ Let us mention only four fragments of Luke's work: "Go and prepare the Passover meal for us that we may eat it" (Luke 22:8); "The teacher asks you, "Where is the guest room, where I may eat the Passover with my disciples?" (Luke 22:11); "So they went and found everything as he had told them; and they prepared the Passover meal" (Luke 22:13); "I have eagerly desired to eat this Passover with you before I suffer" (Luke 22:15). ${ }^{2}$ However, the whole matter is further complicated if we follow the traditional interpretation of John's chronology, according to which Jesus ate his Last

1 Bartnicki, “Ostatnia Wieczerza nową Paschą Jezusa," 16-17; Jankowski, "Eucharystia jako 'nasza Pascha' (1 Kor 5,7)," 89-91; Köstenberger, "Was the Last Supper a Passover Meal?" 24-25; McKnight, Jesus and His Death, 259; Hola, "Paschalny charakter Ostatniej Wieczerzy," 41-44.

2 The Synoptic Gospels give as many as 12 indicators to make us understand that the Last Supper was a Passover meal: Matt 26:17.18.19; Mark 14:12(twice).14.16; Luke 22:7.8.11.13.15. This understanding is confirmed by the place where the meal was held: visiting Jerusalem Jesus stayed overnight in Bethany (Mark 11:12), but he chose to celebrate the Last Supper with his apostles in Jerusalem - the city where according to the Jewish tradition the Passover should take place (Temple Scroll 11Q19 XVII, 6-9; m. Pesahim 5:10). Two more important arguments for the Passover character of the Last Supper are the explanation of the significance of the foods (in this case, bread and wine) that were absent during ordinary Jewish meals, and the singing of hymns (probably the Hallel psalms; Matt 26:30; Mark 14:26). 
Supper the day before other Jews did. ${ }^{3}$ Was it then a traditional Jewish Passover meal? ${ }^{4}$ Even in John's narrative, which seems to suggest that Jesus was dying when the Passover lambs were being sacrificed in the temple court, ${ }^{5}$ the characteristics of the Passover can be seen. ${ }^{6}$

Some of the presented hypotheses concerning the date of the Last Supper refer directly to the schema of the Jewish Passover banquet to show its new elements or the elements Jesus omitted. According to some exegetes, these elements can significantly affect their attempts to determine the date of the Last Supper. It is worth recalling that the Passover celebrations lasted for a week and started on the 14th day of the Jewish month Nisan. Their ceremonial was based on the Book of Exodus: the Passover lamb was sacrificed, its blood using a bunch of hyssop was put on the doorposts, whereas its roasted meat was eaten with unleavened bread that same night (the Passover was often eaten standing, in the posture of travellers, with staffs in their hands, which symbolised people's readiness to go out). ${ }^{7}$

The lamb was usually chosen by the father of the family. The animal had to without blemish as required by the Law. In the temple area, at the entrance to the Court of Priests, the sacrificers received selected lambs to slaughter them at the sound of the horn in accordance with the ritual. The collected blood was splashed on the altar, from where it was swept down into the Kedron Brook through a system of canals, specially prepared for this purpose. The fat and entrails were burned, and only the meat that could be eaten was taken home. ${ }^{8}$ The meat must not be boiled in water, but it had to be roast over the fire, minding that no bones were broken. During the feast, each household member had to play a specific role. The young-

3 Zeitlin, “The Last Supper," 251-252.

4 More on this subject see: Ruckstuhl, Chronology, 17-28.

5 This is the way many exegetes interpret the Johannine account of Jesus' death, but others point out that the Passover lambs were only slaughtered after 3 p.m., when Jesus' passion was over; Pitre, Jesus and the Last Supper, 325-329.

6 Brown, The Gospel According to John, 556. In Brant J. Pitre's opinion (Jesus and the Last Supper, 254) the answer to the question whether the Last Supper was indeed a Passover meal produces far-reaching consequences for the interpretation of the whole episode: "If Jesus celebrated his final meal the evening after the Passover lambs were sacrificed in the Temple, then the Last Supper was clearly a Jewish Passover meal, and everything Jesus did and said at that meal needs to be interpreted in that context. However, if Jesus celebrated his final meal the evening before the Passover lambs were sacrificed in the Temple, then the Last Supper was not a Passover banquet, but some other kind of meal." See Marshall, Lord's Supper, 57-60.

7 Stanisław Bielecki ("Starotestamentalne kalendarze liturgiczne," 268) emphasises the agrarian roots of the festival, "The Unleavened Bread festival contains typical elements of an agrarian festival. Its celebration was combined with the idea of profound renewal. The inspiration for this was the beginning of new harvest. Hence, the old leaven was considered something past and useless. For this reason, unleavened bread, without using any leaven, was eaten for a whole week, in anticipation of a new leaven that is understood as a sign of a radical reappearance of life." Cf. Rosik, Judaizm u początków ery chrześcijańskiej, 108-115.

8 Idelsohn, Jewish Liturgy, 173-187. 
est participant of the feast asked the ritual question about the importance of eating such a meal. ${ }^{9}$ The answer of the father took the form of haggadah, i.e. a story about the history of the feast. When uttering the first blessing, the unleavened bread dipped in red sauce was eaten. To recall the Israelites' bitter fate, the meat was to be consumed with bitter herbs. The supper was accompanied by a ritual of drinking wine, where the third cup, called the "cup of blessing," had the most solemn character. Shortly after that, the Hallel songs (Psalms 112-118) began. The fourth and final cup of wine ended the meal. ${ }^{10}$

\section{Former Hypotheses Concerning the Date of the Last Supper}

The history of exegesis has seen many attempts to establish the chronology of Jesus' last days, including determining the date of the Last Supper. Some hypotheses tend to accept the thesis of the Synoptic Gospels that the Last Supper was highly probably a paschal supper; others choose the version of John in whose interpretation Jesus was dying on the cross at the same time the Passover lambs were being sacrificed in the Temple, and still others try to reconcile both traditions by explaining the discrepancies or recognising that they are only apparent. ${ }^{11}$ At this point, the best-known hypotheses should be discussed; they include the hypothesis of different ways of reckoning a day, the harmonistic hypothesis, the anticipation hypothesis, the hypothesis of moving the date of the Passover celebration and the hypothesis of two calendars (Essene). It should be added that each of them has been modified many times. ${ }^{12}$

\subsection{Hypothesis of Different Methods of Reckoning a Day}

One of the attempts to answer the question of whether Jesus ate the Last Supper with his apostles on Thursday - as the Synoptics say, or rather on Friday - as opted by Saint John, is based on two different ways of reckoning a day. Both methods were used in first-century Palestine. The first practice was preferred by the Pharisees for whom a new day began at sunrise. ${ }^{13}$ Others preferred the second reckoning: a new

According to the Talmudic treatise Pesachim (10:4), they were usually four questions (called Mah Mishtanah, from the first two words of each question), out of which the first question, the most important one, was "Why is tonight different from all other nights?"

10 For a detailed description of the Passover rituals see: de Vaux, Ancient Israel, 484-492; Mickiewicz, Ewangelia według św. Łukasza. Rozdziały 12-24, 432-452.

11 Smith, "The Chronology of the Last Supper," 30-31.

12 Ogg, "The Chronology of the Last Supper," 75-77; Hamilton, "The Chronology," 323-327.

13 de Vaux, Ancient Israel, 181-182. 
day commenced at sunset. If Jesus celebrated his Passover meal on Thursday night after sunset, according to the first method of reckoning a day it was still Thursday, according to the second it was already Friday.

At first glance, such a proposal to resolve the contradiction between John and the Synoptics seems reasonable, but accepting it results in the necessity to agree with the fact that the entire trial of Jesus would have had to take place within a very short time. Yet, there were several interrogations, both before the Jewish and Roman authorities. ${ }^{14}$ While it can be assumed that Jews were concerned about the length of the trial, it is difficult to accept that the Romans worried about its hastiness.

\subsection{Harmonistic Hypothesis}

Two versions of this hypothesis are known: according to the first version, the Last Supper was a Passover meal, and John - to show Jesus as the Lamb of God (John 1:29) - made changes in the chronology for theological purposes; according to the other the Synoptics, also for theological purposes, gave Jesus' last meal with the apostles the character of a Paschal banquet, though it was not really the case.

According to the first version of the harmonistic hypothesis, Jesus observed the Passover with his apostles on the evening of 14 Nisan, and he was crucified the next day - 15 Nisan, when all Jews could have eaten a meal called chagigah. ${ }^{15}$ This interpretation may be based on some Old Testament texts (Deut 16:2; 1 Chr 30:20-24; 35:8-9). ${ }^{16}$ Thus Jesus' meal shared with his apostles was a Passover meal, whereas John, for theological reasons, made textual changes to show Jesus' death at the time the Passover lambs were being slaughtered by the Israelites. ${ }^{17}$

Another version of the hypothesis harmonising the accounts of John and the Synoptics has been proposed by Hans Lessing, who concluded that from the moment of Jesus' arrest to his death there were no discrepancies between the Gospels which set the day of Jesus' death for the time of the preparation of the Sabbath (Mark 15:42; John 19:31.42). In his opinion, the original description of the Passion began with Jesus' arrest. It was only as part of the early catechesis of the Church that the account of the Last Supper was added as a Paschal meal, focusing on theology (the Passover as Jesus' transition from death to life) rather than on chronology. ${ }^{18}$ Therefore, John would have been right, and Jesus' meal with the apostles was not a Passover supper.

14 The hearing before Annas (John 18:13; Luke 22:54), before Caiaphas (John 18:24; Matt 26:57; Mark 14:53), the first hearing before the Sanhedrin (Mark 14:55-64), the second hearing before the Sanhedrin (Mark 15:1a; Matt 27:1), and then the hearing before Pilate (Mark 15:1b; Matt 27:2; Luke 23:1; John 18:28a).

15 Walther, Jesus, das Passahlamm, 74-76; Kedar-Kopfstein, “ח chagh; גרג hgg," 202-210.

16 Lach, "Data Ostatniej Wieczerzy," 405.

17 Sanders, The Historical Figure of Jesus, 285-286; Lohfink, Jezus z Nazaretu, 401.

18 Lessing, Die Abendmahlsprobleme, 250-269. 
It only had the character of Jesus' solemn farewell meal with his apostles, which with time - for theological purposes was interpreted as a Passover meal. ${ }^{19}$

\subsection{Anticipation hypothesis}

Advocates of this hypothesis accept a thesis that Jesus, aware of his impending death, anticipated the paschal supper and consumed it with his apostles on 13 Nisan. It was his personal decision because he was aware that his death was imminent. According to another version of this hypothesis, the anticipation would not only have been Jesus' personal decision, but it also would have complied with Jewish law since according to scholars supporting this hypothesis, during those years when 15 Nisan fell on a Sabbath, the killing of the Passover lambs was done on 13 Nisan, while the lambs were consumed on the 14th or the 15th day of the month. ${ }^{20}$ The idea behind such a procedure was to avoid breaking the Sabbath rest after sacrificing the animal by making necessary preparations for the banquet. ${ }^{21}$

Jesus, therefore, consumed his Last Supper twenty-four hours earlier than every Jew (if it was his sovereign decision) or many Jews (if the Law allowed it); others ate the Passover supper on Friday evening. Adopting this approach, both John and the Synoptics are right, and Jesus' supper with the apostles did indeed have many (though not all) features of a Passover meal. ${ }^{22}$

There are several strong reasons for supporting this hypothesis: no mention of eating roast lamb (cf. Mark 14:12-16; Luke 22:7-8); ${ }^{23}$ a mention in the Babylonian Talmud that Jesus was hanged on the eve of Passover (Sanh. 43a); ${ }^{24}$ the legal inability to perform the activities that led to Jesus' death during the appointed festivals (Lev 23:5-7); ${ }^{25}$ the inability to pass sentences or perform executions on festivals (m. Beitzah 5:2; t. Beitzah 4:4; Philo of Alexandria, De migratione 91$) ;{ }^{26}$ modern

19 Dunn, Jesus Remembered, 772-773; Matson, “The Historical Plausibility," 291-312; Fredriksen, Jesus of Nazareth, 223.

20 Strack - Billerbeck, Kommentar, 812-814; Meineretz, Theologie des Neuen Testaments, 136.

21 Pickl, The Messias, 120-122.

22 Nicholas T. Wright (Jesus and the Victory of God, 556-559) calls such a meal "quasi-Passover meal." Cf. Marcus, "Passover," 303-324; Pitre, Jesus, the Tribulation, 441-442.

23 Schröter, Das Abendmahl, 44.

24 "They hanged Yeshu on the Sabbath of the Passover. But for forty days before that a herald went in front of him (crying), 'Yeshu is to be stoned because he practiced sorcery and seduced Israel and lead them away from God. Anyone who can provide evidence on his behalf should come forward to defend him. When, however, nothing favorable about him was found, he was hanged on the Sabbath of the Passover" (b. Sanh. 43a). [On the basis of http://jewishchristianlit.com//Topics/JewishJesus/b_san43a.html; access 7.07.2020].

25 Brown, The Death of the Messiah, 1358.

26 Philo indeed states that it is not permitted to conduct suits at law and perform executions on days of festivals; however, the context may only refer to the Sabbath. It is not known what festivals the Alexandrian historian had in mind. See Levine, The Misunderstood Jew, 208. 
astronomers' research, according to which in the year $30 \mathrm{AD}$ and the year $33 \mathrm{AD}$ (probable dates of Jesus' death), Friday fell on 14 Nisan (as John stated), and not on 15 Nisan (as the Synoptics tell us). ${ }^{27}$ For these reasons, the anticipation hypothesis has today been adopted by a significant number of scholars.

However, it also has a big group of scholars who put forward important counterarguments. They claim that the accounts of the Last Supper contain references to the Passover lamb, which may be ambiguous for contemporary readers. Why? Because Jews, speaking about the Passover lamb, did not use the noun "lamb" (Greek: arnion), but directly referred to the Passover (e.g. Exod 12:1-14). The phrase "to eat the Passover" (Mark 14:12; Luke 22:15) simply means "to eat the foods prepared for the Passover banquet," that would first of all include roast lamb as its basic meat. ${ }^{28}$

As suggested by the opponents of the hypothesis, the Talmud mentioning the hanging on the eve of Passover does not mean Jesus of Nazareth, but someone else. ${ }^{29}$ It is also possible to justify all the actions of Jesus' adversaries during the feast day. In their opinions, they do not break the Law, which is very restrictive regarding the Sabbath but no other appointed festivals (Lev 23:3.6-7; cf. Num 28:18) ${ }^{30}$ In addition, as the opponents of the hypothesis claim the Mishnah fragment referring to the ban on passing judgments on festivals (Beitzah 5:2) concerns the settlement of ordinary matters by the rabbis (kosher laws, levirate, etc.) and has nothing to do with the Sanhedrin. ${ }^{31}$ Moreover, in Tosefta, the treatise of the Sanhedrin (11:7) mentions that executions of false prophets should be carried out during pilgrims' festivals (Passover, the Feast of Tabernacles and Pentecost), ${ }^{32}$ while the verdict may be issued on the eve of the feast ( $m$. Sanh. 4:1).$^{33}$ Further, the Law explicitly orders seven times that the Passover lambs should be slain on 14 Nisan (Exod 12:6.18; Lev 23:5; Num $9: 3.5 .11 ; 28: 16)$, and there is no witness from the Second Temple period that this date can be altered or that a paschal meal can be eaten without roast lamb. ${ }^{34}$ Finally, astronomers have proven that modern research cannot determine the ancient calendar

27 Humphreys - Waddington, "Astronomy," 165-181; Humphreys - Waddington, "Dating the Crucifixion," 743-746.

28 Barrett, "Luke XXII. 15," 305-307; Jeremias, The Eucharistic Words of Jesus, 18-19.

29 For discussions on this topic see: Maier, Jesus von Nazareth, 263-275. Those opposing this hypothesis include: Schäfer, Jesus in Talmud, 63-74; Wróbel, "Krytyka tekstologiczna," 37-39.

30 Hamilton, Handbook on the Pentateuch, 194: "In contrast to the days of public sacrifices when laborious or heavy work is forbidden (Num. 28:18, 25, 26; 29:1), only on the Sabbath and Yom Kippur /Day of Atonement is no work at all to be done. See Num. 29:7 and Lev. 23:3, 28." Gray, Sacrifice in the Old Testament, 386.

31 Danby, The Mishnah, 187.

32 Jeremias, The Eucharistic Words of Jesus, 78-79; Dalman, Jesus - Jeshua, 98-100.

33 Raymond E. Brown (The Death of the Messiah, 1361) notes that even if it is assumed that some legal acts were prohibited on a festival or its eve, it is not known to what extent this rule was used in the first century. 
since it was based on human observations (e.g. the new moon was sighted), and not on astronomical calculations. ${ }^{35}$

\subsection{Postponement hypothesis}

Christ was to eat the Last Supper as a Passover meal on 14 Nisan in accordance with the Law, but that year the Jewish authorities postponed all the celebrations to Friday, 15 Nisan. ${ }^{36}$ Most scholars reject this hypothesis because there is no example of the practice of transferring a festival by the Sanhedrin, and there must have been no sufficient motive to justify such an action. ${ }^{37}$ Moreover, if the Sanhedrin had actually decided to postpone a festival, it would have seemed strange that Jews obeyed it, but Jesus did not.

\subsection{Two calendar hypothesis (Essene)}

Another attempt to explain the discrepancies occurring in the Gospels as to the date of the Last Supper is based on the fact that at the time of Jesus two distinct calendars were used in Palestine. This hypothesis, sometimes called the "Essene hypothesis," has been proposed by the outstanding scholar Annie Jaubert. ${ }^{38}$ The lunar calendar was adopted in the official Jewish worship in the Temple, which was also supported by the Pharisees who had the greatest influence on popular piety among all Jewish groups.

It was different in the case of the Essenes (Qumran inhabitants). ${ }^{39}$ When in the middle of the second century $\mathrm{BC}$, it became clear that resistance against the Seleucids and Hellenism lost focus, and the descendants of the Maccabees leaned towards compromises, some of the chasidim ("the pious") decided to break their ties with the regime. They went to the desert in the vicinity of the Dead Sea to devote themselves to an ascetic life, filled with rigid observance of the provisions of the Law. Their beliefs were strongly based on the biblical tradition. For them the Torah, revealed to Moses, was the concretisation of the covenant between Yahweh and his people. The only novelty of the Essenes' beliefs was their strong conviction that the end-time prophecies concerned the period in which they lived. Full of charges

35 Beckwith, "The Date of the Crucifixion," 276-296.

36 Łach, "Data Ostatniej Wieczerzy," 405.

37 A different opinion is expressed by Jan Łach ("Data Ostatniej Wieczerzy," 417): "Now the most probable solution to this problem is to assume that in the year of Christ's death, the celebration of the paschal celebration in the Temple was transferred to the Sabbath."

38 Jaubert, "Le calendrier des Jubilés," 35-61; Jaubert, The Date of the Last Supper. Annie Jaubert's opinion has been supported by many scholars: Nodet, "On Jesus' Last Supper," 348-369; Pixner, Paths of the Messiah, 242-244; Pixner, "Mount Zion," 309-322; Saulnier, Calendrical Variations.

39 Smith, "The Chronology of the Last Supper," 30. 
directed against the priests for "teaching lies" and for their moral offenses, the Qumran community expected that after the victory of good in the battle between light and darkness, they would be able to perform pure worship in a temple reconstructed according to divine rules.

According to the Qumran community, an example of "teaching lies" was the adoption of the 354-day lunar calendar in the official worship of Judaism. The Essenes adopted the 364-day solar calendar. ${ }^{40}$ They knew that this calendar was unknown to Israel at the time of David and Solomon, but it was revealed in the exile, at the beginning of the 6th century BC. Since this revelation was God's will, anyone who did not follow this calendar was excluded from the spiritual power of Israel (CD 3:12-17; cf. Jub. 6:36-38). The application of the solar calendar is confirmed by the apocryphal Book of Jubilees (Jub. 6:32-38), the Damascus Document (CD $3: 13-15 ; 6: 18-19 ; 16: 1-5$ ) and the Community Rule (1QS 1:15-16; 10:5-7). A full description of the dates of Jewish festivals was given in the synchronic calendar from Cave 4 (4Q320 fragm. 4, col. 3:1-9), which says that the Passover falls on the third day after the Sabbath of Mo aziah's sons (Tuesday). ${ }^{41}$

Adopting the thesis that the Gospels refer to two different calendars we should state that the Synoptics follow the solar calendar, the one recognised by the Essene community, while John gives the chronology of Jesus' last days in accordance with the official Temple calendar.

The Essene hypothesis would also be supported by the argument concerning the location of the upper room, which - according to many scholars ${ }^{42}$ - was in the Essene district of Jerusalem at "the gate of the Essenes," which is mentioned by Flavius Josephus (Bell. 5.145). So the events should be summarised as follows: the Last Supper was held on Tuesday (Mark 14:17; Matt 26:17; Luke 22:7) ${ }^{43}$ then Jesus was arrested and taken to Annas (John 18:13; Luke 22:54), Peter denied Jesus (John 18:15-27), Jesus was led to Caiaphas (John 18:24; Matt 26:57; Mark 14:53). On Wednesday Jesus stood before the Sanhedrin (Mark 14:55-64), and after being mocked he spent the night in prison. On Thursday morning Jesus was again questioned by the Sanhedrin (Mark 15:1a; Matt 27:1) and later by Pilate (Mark 15:1b; Matt 27:2; Luke 23:1; John 18:28a). Jesus spent the next night in Pilate's prison and the following day, Friday, after another hearing before Pilate (Luke 23:13) he was condemned to death and

40 For a detailed discussion of the differences between the calendars and the consequences that resulted from them see: Talmon, "What's in a Calendar?," 25-58.

41 This Qumranic text presents the chronological synchronisation of the solar and the lunar calendars. See Talmon, "Calendars and Mishmarot," 108-117.

42 They include Bargil Pixner and Reiner Riesner. See Pixner, "Mount Zion," 309-322; Riesner, "Jesus," 198-234.

43 According to the solar calendar the slaughter of the Passover lamb and consuming its roast meat always fell on a Tuesday. See Pitre, Jesus and the Last Supper, 260. 
crucified. ${ }^{44}$ The most important fact in this hypothesis is that the Passover according to the solar calendar always falls on the third day after the Sabbath, i.e. on a Tuesday. On that day, Jesus ate the Last Supper with his disciples and was crucified on Friday, i.e. the day when the Jews celebrating the Passover according to the lunar calendar offered the sacrificial lambs. ${ }^{45}$

The hypothesis of the two calendars has constructively been criticized for decades. Let us list only the serious reservations. The hypothesis opposes the synoptic tradition, according to which Jesus ate the Passover in the evening after the lambs had been sacrificed in the temple (Mark 14:12; Luke 22:7-8). ${ }^{46}$ There are no sufficient arguments that Jesus would follow the Essene calendar, ${ }^{47}$ and that three days had passed between his arrest and death (cf. Mark 14:30.66.72; 15:1; John 13:38). ${ }^{48}$ Also, many Church Fathers seem to reject Jesus' adoption of the solar calendar. ${ }^{49}$ In addition, many scholars believe that there appears no convincing evidence for the existence of an Essene quarter in Jerusalem. ${ }^{50}$ All these arguments weaken the credibility of the two-calendar hypothesis.

\section{Recent Proposals}

Among the latest solutions to the different (or seemingly different) dating of the Last Supper, three positions are worth mentioning. ${ }^{51}$ They are: the modified hypothesis of different methods of reckoning a day, the hypothesis establishing Jesus' Passover as different from the Jewish Passover and the philological hypothesis based on the broad understanding of the term "Passover."

44 Hahn, The Fourth Cup, 66-67. The Essene hypothesis also resolves the apparent chronological discrepancy that according to John's Gospel Jesus was anointed in Bethany six days before the Passover (John 12:1), and according to Mark's Gospel - two days before the Passover (Mark 14:1).

45 That the Last Supper was eaten on Tuesday is confirmed in Didascalia Apostolorum (14:1-9) and by Epiphanes in De fide (22) and Panarion (51:2).

46 See the commentaries on these fragments: Evans, Mark 8:27-16,20, 373; Fitzmyer, The Gospel According to Luke, 1382.

47 Meier, A Marginal Jew, 392; Smith, "The Chronology of the Last Supper," 30.

48 Brown, New Testament Essays, 212-214; Brown, The Death of the Messiah, 1350-1378.

49 Pitre, Jesus and the Last Supper, 274-275.

50 Their list can be seen in Riesner, "Josephus 'Gate of the Essenes," 105-109.

51 Brant J. Pitre (Jesus and the Last Supper, 258-260) distinguishes four positions: the Essene Hypothesis, the Johannine Hypothesis, the Synoptic Hypothesis and the Passover Hypothesis. In this paper the last hypothesis is called "philological" since it is based on the broad understanding of the term "Passover." The division proposed by Pitre seems, however, too arbitrary because scholars supporting the Johannine hypothesis do not completely reject the data contained in the Synoptic Gospels (in my opinion, they followed the Essene calendar), or vice versa, supporters of the Synoptic Hypothesis take into account the data contained in John's narrative, at least trying to explain the inconsistences. 


\subsection{Modified Hypothesis of Different Methods of Reckoning a Day}

Recently Harold Hoehner has proposed a modified version of the hypothesis supporting different methods of reckoning a day. In his opinion, the Galileans (represented by the Synoptics) counted a day from sunrise to sunrise, in contrast to the Judeans (represented by John), who reckoned a day from sunset to sunset. ${ }^{52}$ With this assumption, the Galileans could have offered their Passover lambs the day before the feast. ${ }^{53}$ However, one of the disadvantages of Hoehner's thesis is that no sources confirm that the Galileans and the Judeans calculated the hours of the day in a different way. ${ }^{54}$

\subsection{Hypothesis of Jesus' Passover Different from the Jewish Passover}

Another solution - relatively new - to this chronological problem seems particularly interesting. It can be summed up more or less like this: the Last Supper was indeed a Paschal meal, but it was Jesus' Passover, and not a typical Passover of all Jews. For Jesus makes a certain shift of emphasis which causes that it is no longer about the Passover of the Jews, but about the Passover of Jesus himself as he introduced several novelties into the previously discussed ritual of the Passover meal..$^{55}$ Although the ritual of his meal referred to the Jewish Passover, these novelties made Jesus establish a new ceremonial.

The first novelty would be that there was no roasted lamb during his supper. It should be noted that none of the Evangelists mention the eating of the Passover lamb because Jesus was the "Lamb of God" whose body was to be sacrificed. When the Gospels were written, their authors were well aware that this was how the death on the Cross of the One of whom John the Baptist said "Here is the Lamb of God who takes away the sin of the world" (John 1:29) should be understood. Roman Bartnic-

52 Hoehner, "The Chronology of Jesus," 2348-2349. Cf. Instone-Brewer, Feasts and Sabbaths, 128-135. The latter (122-123) tries to revive the hypothesis put forward by Hermann Strack and Paul Billerbeck, claiming that because of the crowds gathered in the Temple courts the Passover lambs could already have been slaughtered on 13 Nisan. Yet, there are no source materials to support his thesis.

53 Smith, "The Chronology of the Last Supper," 30: "The Pharisees and the Galileans began the day at sunrise, so on Nisan 14 in the afternoon they slaughtered the Passover lambs and held Passover that night, on Nisan 15. Being a Galilean, Jesus celebrated Passover at this time. The Judeans and the Sadducees used a sunset to sunset reckoning. They also slaughtered the Passover on Nisan 14 but according to their reckoning, which put the slaughtering and the eating a day ahead of the Galilean and Pharisaic practice." However, the author does not give any sources of this information.

54 Pitre, Jesus and the Last Supper, 259.

55 Jankowski, "Eucharystia jako 'nasza Pascha' (1 Kor 5,7)," 96-99. 
ki justifies the view as to why, according to some scholars, the Last Supper was not a typical Jewish paschal meal, although it referred to it:

According to Mk 15:34, Jesus died at nine oclock, i.e. 3 p.m. in our reckoning; as John states it was a Friday; Jesus' death took place at the time the lambs were being slaughtered in the Temple. That is why Paul considered Jesus as the Paschal Lamb of the new covenant (1Cor 5:7). The early Church soon saw the slaughter of the lamb whose blood protected people from the angel of death (Ex 12:21-33) as the announcement of Jesus' death that brought freedom from sin and eternal death. Since the Last Supper took place around the date of the Passover, it was easy to interpret it as the Passover of the New Covenant. That is why in the Synoptic Gospels, in the verses constituting the framework of the narrative, it is described as a Passover meal, while it is difficult to consider it as such on the basis of its description. ${ }^{56}$

The second novum concerns the passing of the cup. Luke relates: "Then he took a loaf of bread, and when he had given thanks, he broke it and gave it to them, saying, 'This is my body, which is given for you. Do this in remembrance of me.' And he did the same with the cup after supper, saying, 'This cup that is poured out for you is the new covenant in my blood"' (Luke 22:19-20). Although every participant of the Passover meal had his own cup, Jesus undoubtedly passed to his apostles the cup that was in front of him. ${ }^{57}$ Thus he indicated that the Eucharist he instituted was a meal of unity for the Church that was being born.

The next novelty that Jesus introduced into the established order of the ritual was the omission of the last round of drinking - the fourth cup of wine. When the participants of the meal were to drink the fourth cup, Jesus abstained from it, explaining: "I tell you, I will never again drink of this fruit of the vine until that day when I drink it new with you in my Father's kingdom" (Matt 26:29; cf. Mark 14:25; Luke 22:18). Why? Jesus interrupts the Passover supper to complete it with us in the Father's kingdom. The Last Supper began in the upper room and is continued. It is daily celebrated on the altars of the world, and it will be completed only when in the Father's kingdom Jesus drinks with us the fourth, ending the Passover, cup of

56 Bartnicki, "Ostatnia Wieczerza nową Paschą Jezusa," 17. Many exegetes do not accept this view proving that the Last Supper was an ordinary Passover that Jesus celebrated in the right way. So, e.g.: Pesch, "Geht das Abendmahl," 2-9; Ligier, "De la Cène du Seigneur," 29; Gnilka, Jezus z Nazaretu, 372; Hengel Schwemer, Jesus und das Judentum, 582-586; Szymik, "Żydowska Pascha," 14-18; Pesch, "Das Evangelium in Jerusalem," 113-155. In his earlier publications Roman Bartnicki ("Pascha żydowska," 97-124; "Ewangeliczne opisy męki," 103-143; "Ostatnia Wieczerza a męka Jezusa," 65-85; "Eucharystia w Nowym Testamencie," 14-41; "Eucharystia w Bożym planie zbawienia," 2-16; To czyńcie na moja pamiątkę, 7-24) himself supported the thesis that the Last Supper was a Passover meal.

57 Bartnicki, "Ostatnia Wieczerza nową Paschą Jezusa," 22: "The key to understand their significance is both novelties Jesus introduced into the existing tradition. Contrary to what was practiced, he gave his cup to all the participants of the meal, just like bread was given to everyone, and additionally, he explained his gesture, only now giving them distinct meanings." 
wine. Immediately after singing Hallel Jesus, with the disciples, walked to the Mount of Olives. He did not offer the last cup because his death was the "cup" he had to drink. He asked his apostles: "Are you able to drink the cup that I drink?" (Mark 10:38). In this way the cup became a symbol of the Messiah's death. Consequently, praying in the Gethsemane, Jesus asked the Father to remove "this cup" from him.

In addition, the participants of the Passover included wives and children, while Jesus consumed it with the apostles. ${ }^{58} \mathrm{He}$ did this quite consciously, establishing a new ritual that he wanted to celebrate with his new family - the Church that was being born. ${ }^{59}$ So John was right saying that at the time of Jesus' trial before Pilate, the Jewish authorities had not yet eaten the Passover, and the crucifixion took place on "the day of preparation." ${ }^{60}$ In any case, there is no doubt that Jesus' last meal with the apostles before his death took place in the temporal proximity of the Passover and was held in the atmosphere of this festival. And since some Jews believed that the Messiah would come at Passover, the Evangelists could deliberately have referred to it in order to emphasise the messianic and eschatological nature of the banquet. ${ }^{61}$

Considering that Jesus introduced many new elements into the Jewish Passover, could he not also have postponed the date of its consumption by one day in relation to the date on which all Jews consumed it? Of course, he could. He could have done it quite intentionally to institute a new Passover. ${ }^{62}$

\subsection{Philological Hypothesis ${ }^{63}$}

According to this solution, the contradiction between the chronology of John and that of the Synoptics is only apparent because it is based on the insufficient understanding of ancient Jewish terminology regarding the Passover. Interpreters who emphasise the discrepancies between the Synoptics and John maintain that the fact

\footnotetext{
58 Theissen - Merz, Der historische Jesus, 375.

59 Lohfink, Jezus z Nazaretu, 410.

60 Here it should be assumed that Mark 14:1a and 14:12-16 were later additions to the original corpus of the narrative concerning Jesus' last days. "The entire Johannine tradition, from early to late, agrees perfectly with the primitive Synoptic tradition on the non-Passover character of the meal" - Meier, A Marginal Jew, 398.

61 Bartnicki, "Ostatnia Wieczerza nową Paschą Jezusa," 20.

62 This hypothesis seems to be favoured by Benedict XVI (Jesus of Nazareth, 114) who states: "One thing emerges clearly from the entire tradition: essentially, this farewell meal was not the old Passover, but the new one, which Jesus accomplished in this context. Even though the meal that Jesus shared with the Twelve was not a Passover meal according to the ritual prescriptions of Judaism, nevertheless, in retrospect, the inner connection of the whole event with Jesus' death and Resurrection stood out clearly. It was Jesus' Passover. And in this sense he both did and did not celebrate the Passover: the old rituals could not be carried out when their time came, Jesus had already died. But he had given himself, and thus he had truly celebrated the Passover with them. The old was not abolished; it was simply brought to its full meaning."

63 Recently its ardent advocate and propagator has been B.J. Pitre (Jesus and the Last Supper, 331), although rather unfortunately - calls it "the Passover hypothesis."
} 
that youngest apostle used the term "Passover" three times refers to the sacrifice of the lamb on 14 Nisan. It turns out, however, that in the Hebrew Bible as well as in rabbinic and intertestamental literature, the term has at least four meanings: (1) the Passover lamb slaughtered and sacrificed on 14 Nisan; (2) the Passover meal, during which the offered lamb was eaten (15 Nisan); (3) the Passover peace offering sacrificed and eaten throughout the week: 15-21 Nisan; (4) the Passover week consisting of ongoing paschal celebrations (15-21 Nisan). ${ }^{64}$

Knowing this terminology allows us to prove that the incompatibility between the chronology of the Synoptics and the chronology of John is apparent since John never refers to the first meaning (the lamb offered on 14 Nisan). The term "Passover" as an indication of the Passover lamb that was slaughtered on 14 Nisan, appears several times in the Bible, both in the Old and the New Testament. The Book of Exodus speaks of the need to "slaughter the Passover lamb" (Exod 12:21). Similarly, the author of 2 Chronicles indicates that the slaughtering of the Passover lamb was on "the fourteenth day" (2 Chr 30:15). The Synoptic Gospels use the term in the same sense (Mark 14:12 and Luke 22:7): it means the lamb itself and nothing else.

In the Gospel of St John, the term "Passover" occurs three times in the context of our interest (John 13:1; 18:28; 19:14). "Now before the festival of the Passover" (John 13:1) refers to the meal eaten on 15 Nisan, i.e. the evening of the day the Passover lamb was slain (14 Nisan). When the lamb was slaughtered in the afternoon, it was still 14 Nisan. After sunset it was 15 Nisan, and then the Passover supper began. This was the understanding of the Passover in the apocryphal Book of Jubilees:

Remember the commandments which the Lord gave you regarding the passover so that you may celebrate it at its time on the fourteenth of the first month, that you may sacrifice it before evening, and so that they may eat it at night on the evening of the fifteenth from the time of sunset. For on this night - it was the beginning of the festival and the beginning of joy (...) (Jub. 49:1-2). ${ }^{65}$

This was confirmed by Flavius Josephus who states that to commemorate the exodus from Egypt "we do still offer this sacrifice, in like manner, to this day; and call this festival Pascha" (Ant. 2.313; cf. 3.248; 17.213). ${ }^{66}$ The adherents of this hypothe-

64 Pitre, Jesus and the Last Supper, 331. He adds that the meaning of the word "Passover" in particular cases is determined by its immediate literary context, just like the use of the word "Easter" that can indicate the Easter Vigil, the Easter Sunday or the liturgical Easter season as a whole. Barry D. Smith ("The Chronology of the Last Supper," 33) notes: "But an examination of the use of festival terminology relating to the Passover and the Festival of Unleavened Bread in first-century Palestine found in texts temporally close to the Gospel of John is quite revealing."

65 Vanderkam, The Book of Jubilees, 315.

66 Antiquities of the Jews, translation by William Whiston (The Work of Josephus, 74). 
sis claim that the Synoptics (Matt 26:18 and Mark 14:1) use the term "Passover" in this sense.

So the term "Passover" is used when Jesus was led to Pilate: "Then they took Jesus from Caiaphas to Pilate's headquarters. It was early in the morning. They themselves did not enter the headquarters, so as to avoid ritual defilement and to be able to eat the Passover" (John 18:28). This time - according to the followers of the linguistic hypothesis - the term means a Passover meal eaten on 15 Nisan (after sunset on 16 Nisan), and not the initial meal of the feast consumed after the slaughtering and sacrificing of the lamb. In accordance with the Jewish tradition both the initial meal and the meals eaten throughout the festal week were called "Passover," and ritual purity was required at every meal. ${ }^{67}$ Brant J. Pitre and Gary Anderson prove that the term "Passover lamb" referred to the animal slaughtered on 14 Nisan and to the peace offerings brought during all the festal week until 21 Nisan. ${ }^{68}$

Finally, in the formulation "it wasthedayofPreparation for the Passover" (John 19:14) John refers to the Friday of the Passover week that lasted from 15 till 21 Nisan: "it was the day of Preparation [the Sabbath during the week] for the Passover." ${ }^{69}$ It is not about the day of preparation for the entire festival, but for the Friday of the Passover week, on which Jews made preparations to celebrate the Sabbath that fell during that week.

In other words, Jesus, "having loved his own who were in the world, he loved them to the end" (John 13:1) on 14 Nisan, the time the lamb was being slaughtered and sacrificed, on the same evening (already on 15 Nisan 15 since it was after sunset), ate the Passover meal (John 13:20). Later, in the morning of 15 Nisan, he was led to the praetorium (John 18:28) and the sentence was passed on the same Friday, 15 Nisan (John 19:41), which means that Jesus did not die at the time the Passover lambs were being slaughtered in the Temple, but one day later.

\section{Conclusion}

The issue of the discrepancy, real or apparent, between John the Evangelist and the Synoptics regarding the date of the Last Supper has not been resolved completely.

67 Deut 16:1-3; 2 Chr 35:7-9; Pitre, Jesus and the Last Supper, 333; Smith, "The Chronology of the Last Supper," 37.

68 Pitre, Jesus and the Last Supper, 336: "This [...] definition of Passover is the one with which many readers, even some scholars, are unfamiliar. In order to recognize this usage, it must be stressed that, according to the Jewish Torah, the initial Passover lamb was not the only sacrifice to be offered and eaten during the weeklong festival (15-21 Nisan). Another sacrificial lamb, in the category of a peace offering, was to be offered and eaten over the course of the seven-day festival." Cf. Anderson, "Sacrifice and Sacrificial Offerings," 878.

69 "In the synoptics the term also means Friday, the day before the Sabbath. Mark 15:42 is a case in point" Smith, "The Chronology of the Last Supper," 42. 
For a long time, it was explained by two different ways of reckoning a day, which according to some began at sunrise, while according to others - at sunset. This hypothesis was modified by $\mathrm{H}$. Hoehner, who pointed to different methods of reckoning a day in Galilee and Judea. However, none of the versions have found sufficient arguments to make them convincing. After the Qumran discoveries, a vast majority of biblical scholars referred to different calendars used in Palestine at the time of Jesus. For decades, the hypothesis of the two calendars has been supplemented, but it does not handle all the problems related to the chronology of Jesus' last days. First of all, it does not fully resolve the question why Jesus would follow the calendar adopted by the Qumran community. Neither version of the harmonistic hypothesis overcome the difficulties since it should be assumed that either the Synoptics or John made such significant theological interpretations that they departed from the historical realities, to a large extent undermining the credibility of their descriptions. According to various versions of the anticipation hypothesis, Jesus already ate the Passover meal on 13 Nisan. Although the supporters of this hypothesis put forward arguments of great weight, the counterarguments are equally strong. The hypothesis of transferring the date of the feast by the Sanhedrin seems to be documented to the least extent.

Seemingly, considering the current state of research most arguments support one of the two latest hypotheses: the Passover of Jesus, but not the Passover of the Israelites, and the philological hypothesis. According to the first one, the Last Supper was indeed a paschal feast, but it was Jesus' Passover and not the Passover of all Jews, and therefore, Jesus himself altered the date of the standard Passover supper, just as he modified the old scheme of the Seder or introduced new elements into it. The second hypothesis - philological - is based on the broad understanding of the term "Passover" that can mean either the festal day of 15 Nisan, the entire long-week festival, the Passover lamb or the Passover meal itself.

\section{Bibliography}

Anderson, G., "Sacrifice and Sacrificial Offerings," The Anchor Bible Dictionary (ed. D.N. Freedman) (New York et al.: Doubleday 1992) V, 870-886.

Barrett, C.K., "Luke XXII. 15: To Eat the Passover," Journal of Theological Studies 9 (1958) 305-307.

Bartnicki, R., "Eucharystia w Bożym planie zbawienia (I)," Ruch Biblijny i Liturgiczny 50 (1997) 2-16.

Bartnicki, R., "Eucharystia w Nowym Testamencie," Warszawskie Studia Teologiczne 4 (1991) 14-41.

Bartnicki, R., "Ewangeliczne opisy męki w aspekcie literackim, teologicznym i kerygmatycznym," Grzech - odkupienie - miłość (ed. J. Łach) (Studia z Biblistyki 3; Warszawa: Akademia Teologii Katolickiej 1983) 67-207. 
Bartnicki, R., "Ostatnia Wieczerza a męka Jezusa," Męka Jezusa Chrystusa, 3rd ed. (ed. F. Gryglewicz) (Lublin: RW KUL 1986) 65-85.

Bartnicki, R., "Ostatnia Wieczerza nową Paschą Jezusa (Mk 14, 22-25)," Warszawskie Studia Teologiczne 33/10 (2015) 6-43.

Bartnicki, R., "Pascha żydowska a chrześcijańska ofiara eucharystyczna. Zarys historii obrzędu," Studia Theologica Varsaviensia 18/1 (1980) 97-124.

Bartnicki, R., To czyńcie na moja pamiątkę. Eucharystia w świetle Biblii (Warszawa: Adam 2010).

Beckwith, R.T., "The Date of the Crucifixion. The Misuse of Calendars and Astronomy to Determine the Chronology of the Passion," Calendar and Chronology, Jewish and Christian. Biblical, Intertestamental, and Patristic Studies (Leiden: Brill 2001) 276-296.

Bielecki, S., "Starotestamentalne kalendarze liturgiczne," Życie religijne w Biblii (ed. G. Witaszek) (Lublin: RW KUL 1999) 267-286.

Brown, R.E., The Death of the Messiah. From the Gethsemane to the Grave. A Commentary on the Passion Narratives in the Four Gospels (Anchor Bible Reference Library; New York et al.: Doubleday 1994).

Brown, R.E., The Gospel According to John (Anchor Bible 29-29A; New York: Doubleday 1966-1970).

Brown, R.E., New Testament Essays (New York: Image 1968).

Gray, B.G., Sacrifice in the Old Testament. Its Theory and Practice (New York: Ktav 1971).

Dalman, G., Jesus - Jeshua: Studies in the Gospels (trans. P.P. Levertoff) (New York: Ktav 1929).

Danby, H. (ed.), The Mishnah (London: Oxford University Press 1933).

Dunn, J.D.G., Jesus Remembered (Christianity in the Making 1; Grand Rapids, MI: Eerdmans 2003).

Evans, C.A., Mark 8:27-16,20 (Word Biblical Commentary 34B; Nashville, TN: Zondervan 2001).

Fitzmyer, J.A., The Gospel According to Luke, 2nd ed. (Anchor Bible 28-28A; New York: Doubleday 1985).

Fredriksen, P., Jesus of Nazareth, King of the Jews (New York: Macmillan 1999).

Gnilka, J., Jezus z Nazaretu. Orędzie i dzieje (trans. J. Zychowicz) (Kraków: Znak 1997).

Hahn, S., The Fourth Cup. Unveiling the Mystery of the Last Supper and the Cross (New York: Image 2018).

Hamilton, J.J., "The Chronology of the Crucifixion and the Passover," Churchman 106 (1992) 323-338.

Hamilton, V.P., Handbook on the Pentateuch, 2nd ed. (Grand Rapids, MI: Baker Academic 2005).

Hengel, M. - Schwemer, A.M., Jesus und das Judentum (Geschichte des frühen Christentums 1; Tübingen: Mohr Siebeck 2007).

Hoehner, H., "The Chronology of Jesus," The Handbook for the Study of the Historical Jesus (eds. T. Holmén - S.E. Porter) (Leiden: Brill 2011) 2315-2359.

Hola, K., "Paschalny charakter Ostatniej Wieczerzy a data śmierci Jezusa," Ruch Biblijny i Liturgiczny 38 (1985) 41-44.

Humphreys, C.J. - Waddington, W.G., "Astronomy and the Date of Crucifixion," Chronos, Kairos, Christos. Nativity and Chronological Studies Presented to Jack Finegan (eds. J. Vardaman - E. Yamauchi) (Winona Lake, IN: Eisenbrauns 1989) 165-181.

Humphreys, C.J. - Waddington, W.G., "Dating the Crucifixion,” Nature 306 (1983) 743-746. 
Idelsohn, A.Z., Jewish Liturgy and Its Development (New York: Schocken 1932).

Instone-Brewer, D., "Jesus' Last Supper: the Synoptics and John," Expository Times 112 (2001) $122-123$.

Instone-Brewer, D., Feasts and Sabbaths. Passover and Atonement (Traditions of the Rabbis from the Era of the New Testament 2A; Grand Rapids, MI: Eerdmans 2011).

Jankowski, A., "Eucharystia jako 'nasza Pascha' (1 Kor 5,7) w teologii biblijnej Nowego Testamentu," Ruch Biblijny i Liturgiczny 28 (1975) 89-100.

Jaubert, A., "Le calendrier des Jubilés et les jour liturgiques de la semaine," Vetus Testamentum 7 (1957) 35-61.

Jaubert, A., The Date of the Last Supper (trans. I. Rafferty) (Staten Island, NY: Alba House 1965). Jeremias, J., The Eucharistic Words of Jesus (trans. N. Perrin) (Philadelphia, PA: Fortress 1977).

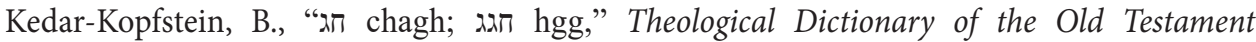
(eds. G.J. Botterweck - H. Ringgren; trans. D.E. Green) (Grand Rapids, MI: Eerdmans 1980) IV, 201-213.

Köstenberger, A., "Was the Last Supper a Passover Meal?" The Lord's Supper. Remembering and Proclaiming Christ until He Comes (eds. T.R. Schreiner - M.R. Crawford) (New American Commentary Studies in Bible \& Theology 10; Nashville, TN: B\&H Academic 2010) 6-30.

Lessing, H., Die Abendmahlsprobleme im Lichte der neutestamentlichen Forschung seit 1900 (Bonn: Bouvier 1953).

Levine, A.-J., The Misunderstood Jew. The Church and the Scandal of the Jewish Jesus (San Francisco, CA: HarperSanFrancisco 2006).

Ligier, L., "De la Cène du Seigneur à la l'Eucharistie," Assemblée du Seigneur 1 (1968) 15-29.

Lohfink, G., Jezus z Nazaretu. Czego chciał. Kim był (trans. E. Pieciul-Karmińska) (Poznań: W drodze 2012).

Łach, J., "Data Ostatniej Wieczerzy w świetle dokumentów znad Morza Martwego," Ruch Biblijny i Liturgiczny 11 (1958) 404-417.

Maier, J., Jesus von Nazareth in der talmudischen Überlieferung (Erträge der Forschung 82; Darmstadt: Wissenschaftliche Buchgesellschaft 1978).

Marcus, J., "Passover and the Last Supper Revisited," New Testament Studies 59 (2013) 303-324. Marshall, I.H., Lord's Supper and Last Supper (Exeter: Paternoster 1980).

Matson, M.A., "The Historical Plausibility of John's Passion Dating," John, Jesus, and History. II. Aspects of Historicity in the Fourth Gospel (eds. P.N. Anderson - F. Just - T. Thatcher) (Atlanta, GA: Society of Biblical Literature 2009) 291-312.

McKnight, S., Jesus and His Death. Historiography, the Historical Jesus, and Atonement Theory (Waco, TX: Baylor University Press 2005).

Meier, J.P., A Marginal Jew. Rethinking the Historical Jesus. I. The Roots of the Problem and the Person (New York et al.: Doubleday 1992).

Mickiewicz, F., Ewangelia według św. Łukasza. Rozdziały 12-24 (Nowy Komentarz Biblijny. Nowy Testament 3/2) (Częstochowa: Edycja Świętego Pawła 2012).

Nodet, É., “On Jesus' Last Supper," Biblica 91 (2010) 348-369.

Ogg, G., "The Chronology of the Last Supper," Theological Collections. VI. Historicity and Chronology in the New Testament (London: SPCK 1965) 75-96.

Pesch, R., "Das Evangelium in Jerusalem. Mk 14, 12-26 als ältestes Überlieferungsgut der Urgemeinde," Das Evangelium und die Evangelien. Vorträge vom Tübinger Symposium 1982 
(ed. P. Stuhlmacher) (Wissenschaftliche Untersuchungen zum Neuen Testament 28; Tübingen: Mohr Siebeck 1983) 113-155.

Pesch, R., “Geht das Abendmahl auf Jesus zurück?," RU an Höheren Schulen 19 (1976) 2-9.

Pickl, J., The Messias (trans. A. Green) (Saint Louis: Herder 1946).

Pitre, B.J., Jesus and the Last Supper (Grand Rapids, MI: Eerdmans 2015).

Pitre, B.J., Jesus, the Tribulation, and the End of the Exile: Restoration Eschatology and the Origin of the Atonement (Grand Rapids, MI: Baker Academic 2005).

Pixner, B., "Mount Zion, Jesus, and Archeology," Jesus and Archeology (ed. J.H. Charlesworth) (Grand Rapids, MI: Eerdmans 2006) 309-322.

Pixner, B., Paths of the Messiah. Jesus and Jewish Christianity in Light of Archeological Discoveries (San Francisco: Ignatius Press 2009).

Ratzinger, J. - Benedict XVI, Jesus of Nazareth. II. Holy Week. From the Entrance into Jerusalem to the Resurrection (San Francisco, CA: Ignatius 2011).

Riesner, R., "Jesus, the Primitive Community, and the Essene Quarter of Jerusalem," Jesus and the Dead Sea Scrolls (ed. J.H. Charlesworth) (New Haven, CT: Yale University Press 1992) 198-234.

Riesner, R., "Josephus 'Gate of the Essenes' in Modern Discussion," Zeitschrift des Deutschen Palästina-Vereins 105 (1989) 105-109.

Rosik, M., Judaizm u początków ery chrześcijańskiej, 2nd ed. (Bibliotheca Biblica; Wrocław: TUM 2008).

Ruckstuhl, E., Chronology of the Last Days of Jesus. A Critical Study (trans. V.J. Drapela) (New York et al.: Desclee 1965).

Sanders, E.P., The Historical Figure of Jesus (London: Penguin Books 1993).

Saulnier, S., Calendrical Variations in Second Temple Judaism. New Perspectives on the 'Date of the Last Supper' Debate (Journal for the Study of Judaism Supplement Series 159; Leiden: Brill 2012).

Schäfer, P., Jesus in Talmud (Princeton - Oxford: Princeton University Press 2007).

Schröter, J., Das Abendmahl. Frühchristliche Deutungen und Impulse für die Gegenwart (Stuttgarter Bibelstudien 210; Stuttgart: Katholisches Bibelwerk 2006).

Smith, B.D., “The Chronology of the Last Supper," Westminster Theological Journal 53/1 (1991) 29-45.

Strack, H. - Billerbeck, P., Kommentar zum Neuen Testament aus Talmud und Midrasch (München: Beck 1952) II.

Szymik, S., "Żydowska Pascha - Ostatnia Wieczerza - Eucharystia," Msza Święta - rozumieć, aby lepiej uczestniczyć. Wykład liturgii Mszy (Poznań: Pallottinum 2013) 14-18.

Talmon, S., "Calendars and Mishmarot," Encyclopedia of the Dead Sea Scrolls (eds. L.H. Schiffman - J.C. VanderKam) (New York: Oxford University Press 2000) I, 108-117

Talmon, S., "What's in a Calendar? Calendar Conformity and Calendar Controversy in Ancient Judaism. The Case of the 'Community of the Renewed Covenant"' The Dead Sea Scrolls and the Qumran Community (ed. J.H. Charlesworth) (The Bible and the Dead Sea Scrolls 2; Waco, TX: Baylor University Press 2006) 25-58.

Theissen, G. - Merz, A., Der historische Jesus (Göttingen: Vandenhoeck \& Ruprecht 1996).

Vanderkam, J.C., The Book of Jubilees (Corpus Scriptorum Christianorum Orientalium 511; Scriptores Aethiopici 88; Louvain: Peeters 1989). 
de Vaux, R., Ancient Israel. Its Life and Institutions, reprint (trans. J. McHugh) (London: Darton - Longman - Todd 1998).

Walther, G., Jesus, das Passahlamm des Neuen Bundes (Gütersloh: Verlag Gütersloh 1950).

Whiston, W. (trans.), The Works of Josephus. Complete and Unabridged. New Updated Edition (Peabody, MA: Hendrickson 1987).

Wright, N.T., Jesus and the Victory of God (Minneapolis, MN: Fortress 1996).

Wróbel, M.S., "Krytyka tekstologiczna i historyczna passusów Talmudu o Jezusie i chrześcijaństwie," Jezus i chrześcijanie w źródłach rabinicznych (eds. K. Pilarczyk - A. Mrozek) (Kraków: Antykwa 2012) 15-50.

Zeitlin, S., "The Last Supper as an Ordinary Meal in the Fourth Gospel," Jewish Quarterly Review $42(1951 / 52)$ 251-260. 